International Journal of English Literature and Social Sciences
Vol-7, Issue-1; Jan-Feb, 2022
Journal Home Page Available: https://ijels.com/
Journal DOI: $10.22161 /$ ijels

\title{
Historical Fiction and Hilary Mantel
}

Peer-Reviewed Journal

\author{
Gudala Parimala, Prof. P. Rajendra Karmarkar
}

Research Scholar (Ph. D.), Andhra University, Andhra Pradesh, India

Parimalagudala518@gmail.com

(Research Supervisor), Principal, College of Arts \& Commerce, Andhra University, Andhra Pradesh, India Karmarkar999@gmail.com

Received: 11 Dec 2021; Received in revised form: 28 Jan 2022; Accepted: 06 Feb 2022; Available online: 14 Feb 2022 (C)2022 The Author(s). Published by Infogain Publication. This is an open access article under the CC BY license (https://creativecommons.org/licenses/by/4.0/).

"I only became a novelist because I thought I had missed my chance to become a historian." _Hilary Mantel

\begin{abstract}
The novel has been a great form of literature and was officially brought into existence and development during the $18^{\text {th }}$ century. Unlike other forms of literature (Drama, and Poetry), the novel has sustained a long time and grew drastically by bringing in several other disciplines into it. The major factors which led to the rise of the novel include the decline of Drama, the rise of middle-class people, leisure among women, modern libraries, and also the industrial revolution. In regard to the development of novels, there has been an emergence of types depending upon the creation, setting, story, and also narration. One among them is the "Historical Novel" which is recognised to be one of the major types of the novel, where the history along with its characters has become alive and revaluated in the present perspectives. "Historical fiction is a literary genre where the story takes place in the past. Historical novels capture the details of the time period as accurately as possible for authenticity, including social norms, manners, customs, and traditions. Many novels in this genre tell fictional stories that involve actual historical figures or historical events."(masterclass.com). As the definition suggests, historical fiction mostly has the characters and the period from the history, and the story is made by the novelist in reference to the history and brought to us in a novel and unseen perspective. In this present article, we focus on the origin and rise of the historical novel and how the British author, Hillary Mantel has used the form widely in her Thomas Cromwell trilogy.
\end{abstract}

Keywords- Novel, History, Historical Fiction, Perspective, Hillary Mantel, Trilogy, Rise, Character, Setting, period.

The historical novel existed and marked its roots in literature as early as the seventeenth and eighteenth centuries but the historical novel is known to have come to light in the nineteenth century after the fall of Napoleon. In the seventeenth and the eighteenth centuries, the historical novels carried the names of the historians and settings but the psychology and inner struggle remained to be contemporary as novels gained their popularity for such realistic and adventurous characters. After the French revolution, Napoleon's rule has brought out a sense of nationalism among the people of France, which further transferred to many other countries like Germany, Poland,
Spain, etc. This progressed after Napoleon's fall and the people were interested to know about their past rulers, cultures, languages, and histories which gave an opportunity for novelists to include not just those characters, but the struggles they had gone through. These experiences of history gave rise to social transformations and their problems; people also knew about the history around the world, not just their respective places. There was also a sense of renewing the whole old laws and times but the history in itself had been of great interest to people and also, the history is better understood through the characters in the stories than to know about it plainly. The progress in human 
minds, Enlightenment, and awareness have been a result of knowing their own history, working on their inner struggle and bringing them to light, and changing it for the better. George Lucaks in his book, 'The Historical Novel' notes that,

"Progress is no longer seen as an essentially unhistorical struggle between humanist reason and feudal-absolutist unreason. According to the new interpretation the reasonableness of human progress develops ever increasingly out of the inner c0onflict of social forces in history itself; according to this interpretation history itself is the bearer and realizer of human progress." (27)

So, the first historians were from the French and they clearly exhibited the class struggle, also as they sought man's internal progress, they understood that man had those similar struggles internally and history had been a basis to expose them. George Lukacs notes,

"Thus, any change in the course of history had meant, in extreme cases, merely a change of costume and, in general. merely the moral ups and down of the same man." (28)

Historical novels have found their place in the path of historicism. Although it started blooming in the nineteenth century, the novelists go back to history to bring out those original characters, settings, culture, language, and even stories. The historical novel is not easy to define as it holds a reputation in all ages, of all ages. Unlike other forms of novels, it doesn't take its characters from the neighbourhood, but from the neighbourhood of the past centuries. Thus, it poses a challenge for the writer to bring out those known characters to the present day, that too from today's perspectives. The Mimesis has played a role in bringing out history, as imitative characters are from the past but they are fictional in nature and the novelist made sure the story and the history are not missed. Yet it delivers a unique representation of characters, which are purely fictional in nature. Barbara Foley in her book 'Telling the Truth' Expresses that,

"The historical novel thus participates in a broader transformation of historical consciousness. Its emergence as an unabashedly fictional kind of writing signals not its abandonment of the claim to represent historical actuality but its reformulation of this claim in accordance with a changing conception of that actuality" (144)

The author needs to create the characters in a way that they are real yet fictional as the story happened in history or the person's inner struggles of that time can only be imagined as they were never recorded and can't prove to be accurate even if they did. The same applies to plot as well because if the novelists had said a plain literal story, it would be nothing but repetition, so they need to work on not missing the historical events happening and the story appearing to be of that period, and the content and happenings being relatable to those times but fictional as they don't present history but a novel based on history. The data, references, and outline stories, the author produces from the period should be true and they should be able to take us to the past with interest and curiosity to know about the real history of the period. As time passed, there is a lot of multidimensional analysis, points of view, gender equality, and the world has changed for the better and taught them to look different than before and this is what the authors of historical fiction show to society and readers. The reader lives in the period of the novel, experiences it, learns from it, understands it but the characters are easily presumed to be relevant even today.

The first novelist to combine real-life situations with an old romance and use the setting and characters of the past history which also included his national patriarchy was Sir Walter Scott. Sir Walter Scott was born in Edinburgh in 1771 into an upper-middle-class family. He has favoured Scottish tradition, later studied Scottish law, and was interested in relations between England and Scotland, which in turn grew in him a national spirit reflected in his novels. His first novel Waverly has a lot of Scottish features which portrayed the Scottish people of all classes, cultures, and also national identities. This has marked the origin of the historical Novels as a separate genre has emerged with Walter Scott. He has been the pioneer and was considered to be the father of Historic Novels. Even though he has considered to be the main person in bringing out a new genre, his novels carry history only to a part where he doesn't bring the other day struggles but includes the present-day struggles and connects them to history, but he gained attention and popularity as the characters from the past has impacted and influenced many from the contemporary society and also he helped people to know about the history and culture, their relationships over the generations, which has given a lively view about the nation and the world. In his other novels, he has dealt with the struggles of Anglo Saxon and Norman people, the defeat of the society and its clans of the times, the ethnic and moral conflicts which also include class conflicts. The novels of Walter Scott have laid a foundation for the use of historical events and settings, which later brought into them the 
characters, struggles, and the whole history which made the genre into a wider form of literature. The immediate influence of this genre is seen in some of his contemporaries like Goethe, Balzac, Pushkin, and also the European and American writers. Other important historical novelists around the time are Aleksey Nikolayevich Tolstoy, Charles Dickens, Victor Hugo, Leo Tolstoy, Robert Graves, William Golding, and many more.

In the twentieth century, women have been avid readers of historical fiction and there were plenty of women writers who considered historical fiction along with romance and escapism. Diana Wallace in her book, 'Woman's Historical Novel' notes that,

"The sheer number of historical novels published by women writers over the twentieth century is a testament to the importance of the form. The sales and public library borrowing figures indicate the wide readership for many of the popular historical novelists." (17)

Women have received citizenship and also many other comforts after the first world war, which helped them to utilise their leisure time in book-reading; and it also made many of them, writers. Not just in this profession, but women were given freedom and liberty which helped them to take up various jobs for the first time. Again, this was class-based as the high and low class remained steady, but the middle-class has thrived to become equals in the society and mostly, in their workplaces. All of this has led to a greater movement among women, where they were interested to read about their past women who encountered many challenges and were inside the homes for centuries; and wanted to fight for their freedom, rights, and equality in society. The historical novels by women rose in number mostly during the 1930s, and they started to pen down the different struggles women in history faced and how they balanced them all along the time. Women also gave their own perspectives to the characters of the past centuries and made it wholly a new form with the same existential and psychological struggles, to which, women have been the victims regardless of the situation and period, which almost continued even to the present day. Diana Wallace expresses,

"Women's historical novels in the 1930s often show a young woman similarly caught between opposing historical forces but rather than demonstrating the inevitability of progress, they frequently depict her being destroyed by the conflict. Women are revealed as the victims, the defeated, in any kind of historical conflict." (57)
This has made women become writers to express their viewpoints, struggles, and fight for their rights. Whereas historical novelists exposed the past women, feminist writers have started to make their future better with their writings in different forms of genres. Some writers of the period are Phyllis Bentley, Sylvia Townsend Warner, Daphne du Maurier, Mary Renault, and many more. The Historical novel has been prevalent even more in the contemporary period and there are many historical novelists, and there are many women who brought the past centuries before us in fictional form. One outstanding historical novelist of the contemporary time is Hilary Mantel, who has written a trilogy on Thomas Cromwell, The minister of Henry VIII dating back to the $16^{\text {th }}$ century. Others include Isabel Allende, Philippa Gregory, Bernard Cornwell, Sarah Waters, Ken Follett, Graham Greene, George Saunders, Shirley Hazzard, and Julie Orringer. Standing out among many, Hilary Mantel has left everyone in the amusement for fictionalising her novels embedded in history and she expresses that,

"Different types of historical novels require different kinds of preparatory work, all of the intensive. Even if you simply use the past as a backdrop, you need to be grounded in the culture; you need to know about everyday life, how people think, what is the story they tell about themselves and their world." (historyextra.com)

Hilary Mantel was born in Derbyshire, England on $6^{\text {th }}$ July 1952. She was born in a working-class, RomanCatholic family to Margeret nee Foster and Henry Thompson, she studied at St. Charles Roman Catholic primary school. She studied law at the London School of Economics and later studied at the University of Sheffield. She worked as a social worker, and also as a store assistant and after that, she continued her career in writing. She got married to a geologist named Gerald McEwen in 1973 and she has been through many illnesses which made her suffer both physically and mentally but none of them have stopped her from becoming a great novelist of the time. She was awarded primarily for her articles and later she began to write novels and memoirs. Her works include Eight Months on Ghazzah Street, Fludd, A Place of Greater Safety, A Change of Climate, An Experiment in Love, The Giant O' Brien, Giving up the Ghost, The Thomas Cromwell Trilogy namely, Wolf Hall, Bring up the Bodies, and Mirror and the Light, and some short stories. She was awarded the Man Booker Prize twice in 2009 and 2012 for her novels, Wolf Hall and Bring up the Bodies respectively, and won many other prizes. She has spent almost 15 years writing historical fiction which turned out to be a great success in the present 
day among many. Her Characters, setting, problems, and inner and political struggle seem to be very authentic where one can easily mistake it for a real history but she herself considers it to be an invention as it holds and exposes the created thoughts of people who were long dead and were just remained in the history outwardly. Historical Fiction is never an easy task because one cannot create the plot and characters outside the period and one cannot write history for that matter, it needs a lot of creativity, understanding the psychology of humans around the periods, use of the culture and language and bring out finally as a fiction which is equally known and unknown. It has been the same to Hilary Mantel and she has mastered it and almost shed a part of her life studying about the Tudors and marking everything at its right place.

Hilary Mantel in her Trilogy shifts back to the $16^{\text {th }}$ century where Henry VIII was the ruler and Thomas Cromwell was his minister. The whole Trilogy was written from Thomas Cromwell's perspective, made the world understand his childhood to his last days along with many other ideologies, which mostly appears to be the reversal of the original history as Thomas Cromwell expresses his points and defends himself yet exposes his weaknesses and wrongdoings as a person. Even though this is fiction, Hilary Mantel has written this in an authentic historical form under consecutive historical events.

In the first novel, Wolf Hall, Hilary Mantel begins with the childhood of the central character named Thomas Cromwell, which was introduced to the readers with a bloody scene that clearly makes us remember the history of the time. But the image portrayed by the author in this is remarkable and it is only possible with a great study of history and a deep understanding of human nature, and its sufferings as a whole. She brings out how Thomas Cromwell as a person overcame the violence in his childhood from his own father and has been a person of intellect and wisdom who has studied law and been a trusted advisor under Cardinal Wolsey, one of the important members of the kingdom. The Story Continues with his growth and also takes us into his personal life, marriage, and children, and also it reveals to us his beliefs. As the story continues it shifts its importance to the other characters but with Thomas Cromwell's perception. It discusses the events of the kingdom, like the King's annulment with his first wife Katherine and marriage to another lady named Anne Boleyn and the novel ends with the marriage where Thomas Cromwell comments his own understanding of the events around him.

The next novel, Bring up the Bodies is a sequel to Wolf Hall and the story continues in the same perspective. The second novel turns mostly around King Henry VIII and his second wife, Anne Boleyn. In this novel, Hilary Mantel brings out another problem of the same kind from the King, where the King is now unhappy with his second marriage and wants to end it for the same reason, as he did the earlier one. Thomas Cromwell as his minister plays a vital part in the king's decision and helps him to make his will true. He uses and manipulates everything politically, using religion, and makes everything suitable for the king to divorce his second wife. As a result, Thomas Cromwell tries to spoil her reputation in the kingdom which will take her out of the throne and lose her status as the King's wife. The Character of Anne Boleyn is expanded in this novel and she tries her best to stay in her position which she ultimately fails to accomplish, through which Hilary Mantel clearly points us to the women victims in history. Hilary Mantel even delivers the story from Thomas Cromwell's perspective, he was portrayed as an evil person who goes to any extent to make anything possible. The novel ends with another wedding of the king with Jane Seymour, for which Thomas Cromwell collects his position as the King's chief adviser.

The Last book, Mirror and the Light is again a sequel to the other two, and the story begins where it ends as Hilary Mantel takes Thomas Cromwell to the ends of height, and then the downfall clearly follows. Thomas Cromwell's trust in the King and his thoughts about the king protecting him have all been in vain and Hilary Mantel keeps this to the end. Meanwhile, the king wants to divorce his third wife, Jane Seymour for the same reason, and Thomas Cromwell again comes to the rescue for this. Even being warned by the Archbishop of Canterbury, Thomas Cranmer, to not enter into the issue of king's marriage, Thomas Cromwell was involved in this and thinks he was the nearest person to the king and that alone would save him from any obstacles he might face but that trust alone has brought him the downfall. King did not save Thomas Cromwell, from being executed, when he was trapped by his enemies who are expecting his place for a long time, at last, he was beheaded at Tower Hill.

The three novels stand as a whole piece of fiction in reality and are an example of Hilary Mantel's intellect and abilities of expression. The historical novelist first becomes a historian to rewrite history more creatively and interestingly, than anyone would be able to believe if it is presented as real history. Hilary Mantel's depiction has been wide and deep in her novels and these novels clearly give her the credit as a great historical novelist of the time. Historical Fiction as a genre has been true and clearly presented by Hilary Mantel as she covered every single character of the period and gave them a role of their potentiality as inventing or imagining the thoughts of many characters is not considered an easy job. This piece of work 
alone brings Hilary Mantel the glory of the time and further as a remarkable historical novelist.

\section{REFERENCES}

[1] Mantel, Hilary. Wolf Hall. 4th Estate, 2009, London.

[2] Lukacs, George. The Historical Novel. Merlin Press, 1989, London.

[3] Wallace, Diana. The Woman's Historical Novel. Palgrave Macmillan, 2005, New York.

[4] Shaw, Harry E. The Forms of Historical Fiction. Cornell University Press, 1983, London.

[5] Butterfield, Herbert. History and Human Relations. Collins, 1951, London.

[6] Orel, Harold. The Historical Novel from Scott to Sabatini. St. Martin's Press, 1995, London.

[7] Polard, Eileen. Carpenter, Ginette. Hillary Mantel. Bloomsbury Academic, 2018, New York.

[8] Arnold, Lucy. Reading Hilary Mantel. Bloomsbury Academic, 2020, Newyork.

[9] MacCulloch, Diarmaid. Thomas Cromwell. Penguin books, 2018, London.

[10] Boccardi, Mariadele. The Contemporary British Historical Novel. Palgrave Macmillan, 2009, London.

[11] Procter, James. "Hilary Mantel". British Council. accessed 1 Feb 2022, literature.britishcouncil.org.

[12] Attar, Rob. "Hilary Mantel on the secrets of successful historical fiction". History Extra. 28 July 2020, historyextra.com 